$$
\text { DOE/PC/79931- T10 }
$$

\title{
OXYGEN ELECTRODE IN MOLTEN CARBONATE FUEL CELLS
}

(CONTRACT NUMBER: DE-FG22-87PC79931)

Ninth Quarterly Technical Progress Report

(August 1, 1989 - October 31, 1989)
DOE/PC/79931--TMO

DE92 019712

\section{PERSONNEL:}

Bhasker B. Dave*, Supramaniam Srinivasan

Ralph E. White*, and A. John Appleby

Center for Electrochemical Systems and Hydrogen Research

Texas Engineering Experiment Station

238 Wisenbaker Engineering Research Center

Texas A\&M University System

College Station, Texas $\mathbf{7 7 8 4 3}$

* Department of Chemical Engineering, Texas A\&M University

College Station, Texas 77843

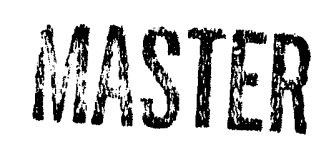




\begin{abstract}
The oxygen reduction reaction on a gold electrode in lithium carbonate melt was investigated to determine the influence of partial pressure of carbon dioxide and temperature on electrode kinetics and oxygen solubility by using cyclic voltammetry and impedance analysis techniques. During this quarter, the impedance data were analyzed by a Complex Nonlinear Least Square (CNLS) parameter estimation program to determine the kinetic and the mass transfer related parameters such as charge transfer resistance, double layer capacitance, solution resistance, and Warburg coefficient. The estimated parameters were used to obtain the $\mathrm{CO}_{2}$ reaction orders and apparent activation energies for the exchange current density and the mass transfer parameter $\left(D_{O}^{1 / 2} C_{O}^{*}\right)$.
\end{abstract}

\title{
DISCLAIMER
}

This report was prepared as an account of work sponsored by an agency of the United States Government. Neitker the United States Government nor any agency therenf, nor any of their employees, makes any warranty, express or implied, or assumes any legal liability or responsibility for the accuracy, completeness, or usefulness of any information, apparatus, product, or process disclosed, or represents that its use would not infringe privately owned rights. Refer. ence herein to any specific commercial product, process, or service by trade name, trademark, manufacturer, or otherwise does not necessarily constitute or imply its endorsement, recommendation, of favoring by the United States Government or any agency thereof. The views and opinions of authors expressed herein do not necessarily state or reflect those of the United States Government or any agency theresf. 


\title{
OXYGEN ELECTRODE IN MOLTEN CARBONATE FUEL CELLS
}

\author{
Introduction
}

This project focuses on three area of research:

Task 1: Construction of High Temperature Equipment

Task 2: Microelectrode Study of Oxygen Reduction

Task 3: $\quad$ Computer Modeling of Reactions

\section{Work Carried Out During the Reporting Period}

\section{Task 2: Microelectrode Study of Oxygen Reduction}

Prior to initiating the experimental studies with the microelectrode, it was considered necessary to test the experimental set up with macroelectrodes. For this purpose, oxygen reduction reactions were investigated on a gold electrode in $\mathrm{Li}_{2} \mathrm{CO}_{3}$ melt as a function of temperature and $\mathrm{PCO}_{2}$.

\section{Effect of $\mathrm{PCO}_{2}$}

The experimental arrangement and the electrochemical cell assembly for high temperature electrode kinetics study is described in the previous report (1). The working electrode was made of a submerged gold flag with a geometrical area of one $\mathrm{cm}^{2}$. The counter and reference electrodes were large gold foils. The digital mass flow controllers/meters manufactured by Teledyne-Hastings Raydist provided the gas mixtures of desired compositions $\left(\mathrm{O}_{2}, \mathrm{CO}_{2}\right.$ and $\left.\mathrm{Ar}\right)$ with high precision ( $\pm 1 \%$ Full Scale). The gas mixtures bubbled in the vicinity of the 
reference and the working electrodes were of the same composition, but at different flow rates. For this study, $\mathrm{FCO}_{2}$ was varied from 0.02 to 0.4 atm., while $\mathrm{P}_{\mathrm{O}_{2}}$ was kept constant at $0.6 \mathrm{~atm}$. The data acquisition set up consisting of potentiostat/galvanostat (Model 273), lock-in-amplifier (Model 5301A), personal computer (IBM PS/2), and software (Model 378) supplied by EG\&G PAR was used for impedance measurements.

\section{Impedance Measurements and Analyses}

The impedance measurements for oxygen reduction in $\mathrm{Li}_{2} \mathrm{CO}_{3}$ melt were carried out at the rest potential as a function of $\mathrm{P}_{\mathrm{CO}_{2}}$, temperature and frequency $(0.05 \mathrm{~Hz}-10 \mathrm{kHz})$. The effect of $\mathrm{P}_{\mathrm{CO}_{2}}$ on the Bode plot (phase angle vs. $\log \omega$ ) were described in the last report (1). During this quarter, the impedance data were analyzed using a CNLS parameter estimation program (2-3) to determine the kinetic and mass transfer related parameters. The Randles-Ershler equivalent circuit used in the impedance analysis is shown in Fig. 1. These analyses estimated parameters such as charge transfer resistance $\left(R_{c t}\right)$, double layer capacity $\left(C_{d l}\right)$, Warburg coefficient $(\sigma)$, and solution resistance $\left(R_{s}\right)$. The effect of $\mathrm{P}_{\mathrm{CO}_{2}}$ on real impedance $\left(Z^{\prime}\right)$ vs. inverse square root of angular frequency $\left(\omega^{-1 / 2}\right)$ are shown in Figs. $2-4$ for temperatures 750,800 , and $850^{\circ} \mathrm{C}$ respectively. In a low frequency region, $Z$ ' vs. $\omega^{-1 / 2}$ plots showed a linear behavior with slope proportional to the Warburg Coefficient $(\sigma)$. As shown in Fig. 2, the Warburg coefficient increased with the increase in $\mathrm{PCO}_{2}$ due to decrease in the peroxide ion concentration. The symbols in Figs. $2-4$ show $Z$ vs. $\omega^{-1 / 2}$ plots for the experimental data and the curve lines represent the data computed by the model using estimated parameters. The estimated parameters for various partial pressures of carbon dioxide and temperatures are given in Tables 1-3. These tables show that 
the decrease in $\mathrm{PCO}_{2}$ and increase in temperature, decreased the charge transfer and mass transfer impedances, whereas the change in the solution resistance was negligible. The double layer capacity increased with decrease in $\mathrm{PCO}_{2}$, and increase in temperature. The effects of $\mathrm{PCO}_{2}$ and temperature on the impedance spectrum can also be observed by $\log |Z|$ vs. $\log \omega$ plots shown in Figs. 5-7. In the high frequency region, $\log |Z|$ vs. $\log \omega$ plot approached the uncornpensated resistance between the working and the reference electrodes which is independent of the frequency. In the low frequency region, complete relaxation of the charge transfer process $\left(R_{c l} C_{d l}\right)$ is not observed due to the Warburg (mass transfer) impedance. These figures showed good agreement between the experimental and model data for the entire frequency spectrum.

Since impedance measurements were obtained at the rest potential, the following expressions can be used for the charge transfer resistance and Warburg coefficient (4):

$$
\begin{gathered}
R_{c t}=\frac{R T}{n F i_{o}} \\
\sigma=\frac{R T}{n^{2} F^{2} A \sqrt{2}}\left(\frac{1}{D_{O}^{1 / 2} C_{O}^{*}}+\frac{1}{D_{R}^{1 / 2} C_{R}^{*}}\right)
\end{gathered}
$$

For peroxide reduction in $\mathrm{Li}_{2} \mathrm{CO}_{3}$ melt, $\mathrm{C}_{O}^{*}$ is much smaller than $\mathrm{C}_{R}^{*}$ because the final product is carbonate ion. Therefore $1 / D_{R}^{1 / 2} C_{R}^{*}$ is negligible compared with 1/D $\mathrm{D}_{\mathrm{O}}^{1 / 2} \mathrm{C}_{\mathrm{O}}^{*}$. Thus Eqn. [2] can be approximated by the following expression:

$$
\sigma=\frac{\mathrm{RT}}{\mathrm{n}^{2} \mathrm{~F}^{2} A \sqrt{2}}\left(\frac{1}{\mathrm{D}_{\mathrm{O}}^{1 / 2} \mathrm{C}_{\mathrm{O}}^{*}}\right)
$$

Using eqn. [1] (where $n=2$, for peroxide reduction), the exchange current density (io) was calculated as a function of $\mathrm{P}_{\mathrm{CO}_{2}}$ and temperature; the exchange current density values are given in Tables 1-3. The plots of the $\log$ io vs. $\log \mathrm{PCO}_{3}$ are 
shown in Fig. 8, which were used to estimate the reaction order of -0.5 with respect to carbon dioxide. The theoretical $\mathrm{CO}_{2}$ reaction order for the reaction mechanism described in the last report $(5)$ is -1.25 . The Arrhenius plots of $\log i_{0}$ vs. $1 / \mathrm{T}$ are shown in Fig. 9 for various values of $\mathrm{PCO}_{2}$ and the average activation energy was calculated to be $131.8 \mathrm{~kJ} \mathrm{~mol}^{-1}$. The mass transfer parameter, $\mathrm{D}_{\mathrm{O}}^{1 / 2} \mathrm{C}_{\mathrm{O}}^{*}$, was calculated using eqn. [3]. As shown in previous report (5), the mass transfer parameter estimated by impedance analysis and cyclic voltarnmetry techniques were in good agreernent. The $\mathrm{CO}_{2}$ reaction order plots for $\mathrm{D}_{\mathrm{O}}^{1 / 2} \mathrm{C}_{\mathrm{O}}^{*}$ values obtained from impedance analysis are shown in Fig. 10. The $\mathrm{CO}_{2}$ reaction order was calculated to be -0.8 , which is very close to the value obtained by cyclic voltammetry. The Arrhenius plots of $\log D_{O}^{1 / 2} C_{O}^{*}$ vs. $1 / T$ for various values of $\mathrm{P}_{\mathrm{CO}_{2}}$ are shown in Fig. 11; the slopes of these lines are nearly identical and the apparent activation energy was calculated to be $184.5 \mathrm{~kJ} \mathrm{~mol}^{-1}$, which is very close to the values available in the literature $(6,7)$.

\section{Task 3: Computer Modeling of Reactions}

Work carried out under this task is already described in Impedance Measurements and Analysis section of Task 2.

\section{PROPOSED WORK DURING NEXT QUARTER}

\section{Task 2:}

1. Investigation of the stability of ceramic adhesives in a molten carbonate environment.

2. Fabrication and testing of gold microelectrodes. 


\section{Task 3 :}

1. Develope differential equation model for impedance analysis. 


\section{References}

1. Second Quarterly 'Technical Progress Report, (November 1, 198'7-January $31,1988)$.

2. J. R. Macdonald, J. Electroanal. Chem., 223, 25 (1987).

3. J. R. Macdonald, in "Impedance Spectroscopy," , J. R. Macdonald, Editor, p. 1, John Wiley \& Sons, New York, (1987).

4. M. Sluyters-Rehbach and J. H. Sluyters, in "Electroanalytical Chemistry," Vol. 4, A. J. Bard, Editor, p. 1, Marcel Dekker, New York, (1970).

5. Eighth Quarterly Technical Progress Report, (May 1, 1989 - July 31, 1989).

6. A. J. Appleby and S. B. Nicholson, J. Electroanal. Chem., 53, 105 (1974).

7. A. J. Appleby and Van Drunen, J. Electrochem. Soc., 127, 1655 (1980). 
Table 1. Parameters Estimated by Impedance Analysis Using CNLS Program: Temperature $750^{\circ} \mathrm{C}$ and 0.6 atm. $\mathrm{P}_{\mathrm{O}_{2}}$.

\begin{tabular}{|c|c|c|c|c|c|}
\hline $\mathrm{CO}_{2}: \mathrm{O}_{2}: \mathrm{Ar}$ & $\begin{array}{c}\sigma \\
\Omega s^{1 / 2}\end{array}$ & $\begin{array}{c}\mathrm{R}_{\mathrm{ct}} \\
\Omega\end{array}$ & $\begin{array}{c}\mathrm{i}_{0} \\
\mathrm{~mA} / \mathrm{cm}^{2}\end{array}$ & $\begin{array}{c}\mathrm{C}_{\mathrm{dl}} \\
\mu \mathrm{F}\end{array}$ & $\begin{array}{c}\mathrm{R}_{\mathrm{s}} \\
\Omega\end{array}$ \\
\hline $2: 60: 38$ & 27.3 & 0.53 & 84.0 & 558.0 & 0.51 \\
$4: 60: 36$ & 47.2 & 0.62 & 71.7 & 388.6 & 0.50 \\
$8: 60: 32$ & 82.9 & 1.05 & 41.9 & 312.5 & 0.38 \\
$20: 60: 20$ & 158.6 & 1.55 & 28.5 & 255.9 & 0.36 \\
\hline
\end{tabular}

Table 2. Parameters Estimated by Impedance Analysis Using CNLS Program: Temperature $800{ }^{\circ} \mathrm{C}$ and 0.6 atm. $\mathrm{P}_{\mathrm{O}_{2}}$.

\begin{tabular}{|c|c|c|c|c|c|}
\hline $\mathrm{CO}_{2}: \mathrm{O}_{2}: \mathrm{Ar}$ & $\begin{array}{c}\sigma \\
\Omega s^{1 / 2}\end{array}$ & $\begin{array}{c}\mathrm{R}_{\mathrm{ct}} \\
\Omega\end{array}$ & $\begin{array}{c}\mathrm{i}_{0} \\
\mathrm{~mA} / \mathrm{cm}^{2}\end{array}$ & $\begin{array}{c}\mathrm{C}_{\mathrm{dl}} \\
\mu \mathrm{F}\end{array}$ & $\begin{array}{c}\mathrm{R}_{\mathrm{s}} \\
\Omega\end{array}$ \\
\hline $2: 60: 38$ & 10.4 & 0.23 & 205.7 & 1209.2 & 0.50 \\
$4: 60: 36$ & 18.4 & 0.40 & 115.9 & 715.0 & 0.53 \\
$8: 60: 32$ & 31.7 & 0.58 & 79.4 & 508.6 & 0.37 \\
$20: 60: 20$ & 63.2 & 0.83 & 55.7 & 329.5 & 0.37 \\
$40: 60: 00$ & 103.3 & 1.28 & 36.2 & 277.8 & 0.40 \\
\hline
\end{tabular}


Table 3. Parameters Estimated by Impedance Analysis Using CNLS Program: Temperature $850^{\circ} \mathrm{C}$ and 0.6 atm. $\mathrm{P}_{\mathrm{O}_{2}}$.

\begin{tabular}{|c|c|c|c|c|c|}
\hline $\mathrm{CO}_{2}: \mathrm{O}_{2}: \mathrm{Ar}$ & $\begin{array}{c}\sigma \\
\Omega s^{1 / 2}\end{array}$ & $\begin{array}{c}\mathrm{R}_{\mathrm{ct}} \\
\Omega\end{array}$ & $\begin{array}{c}\mathrm{i}_{0} \\
\mathrm{~mA} / \mathrm{cm}^{2}\end{array}$ & $\begin{array}{c}\mathrm{C}_{\mathrm{d} \mathrm{I}} \\
\mu \mathrm{F}\end{array}$ & $\begin{array}{c}\mathrm{R}_{\mathrm{s}} \\
\Omega\end{array}$ \\
\hline $2: 60: 38$ & 4.3 & 0.14 & 358.5 & 3161.8 & 0.51 \\
$4: 60: 36$ & 6.9 & 0.18 & 273.4 & 1874.2 & 0.59 \\
$8: 60: 32$ & 13.3 & 0.27 & 179.3 & 883.7 & 0.39 \\
$20: 60: 20$ & 27.0 & 0.47 & 102.8 & 510.8 & 0.37 \\
$40: 60: 00$ & 47.7 & 0.59 & 81.6 & 376.6 & 0.40 \\
\hline
\end{tabular}

Table 4. Effect of $\mathrm{P}_{\mathrm{CO}_{2}}$ on Activation Energies for the Oxygen Solubility and the Oxygen Reduction Kinetics at 0.6 atm. $\mathrm{P}_{\mathrm{O}_{2}}$.

\begin{tabular}{|c|c|c|c|}
\hline & \multicolumn{3}{|c|}{ Activation Energy, $\mathrm{kJ}^{-1} \mathrm{~mol}^{-1}$} \\
\hline Arrhenius Plot & \multicolumn{2}{|c|}{$\log \mathrm{D}^{1 / 2} \mathrm{C}^{*}$ vs. $\mathrm{T}^{-1}$} & $\mathrm{i}_{0}$ vs. $\mathrm{T}^{-1}$ \\
\hline $\mathrm{P}_{\mathrm{CO}_{21} \text { atm. }}$ & $\begin{array}{c}\text { Cyclic } \\
\text { voltammetry }\end{array}$ & $\begin{array}{c}\text { Impedance } \\
\text { Analysis }\end{array}$ & $\begin{array}{c}\text { Impedance } \\
\text { Analysis }\end{array}$ \\
\hline 0.02 & 183.6 & 183.4 & 139.1 \\
0.04 & 192.4 & 192.6 & 127.3 \\
0.08 & 179.7 & 184.1 & 138.5 \\
0.20 & 167.2 & 177.9 & 122.4 \\
\hline Average & 176.6 & 184.5 & 131.8 \\
\hline
\end{tabular}




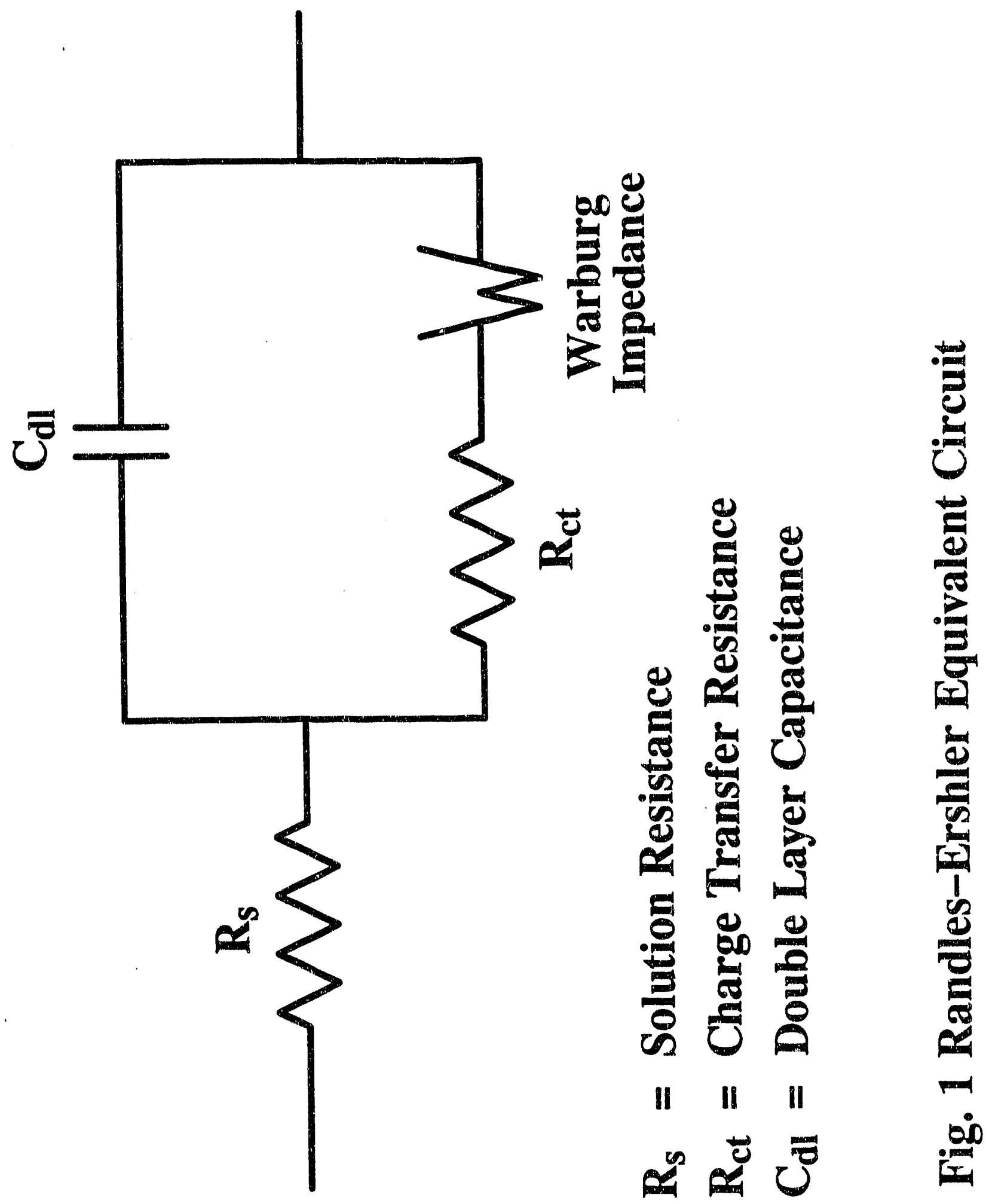




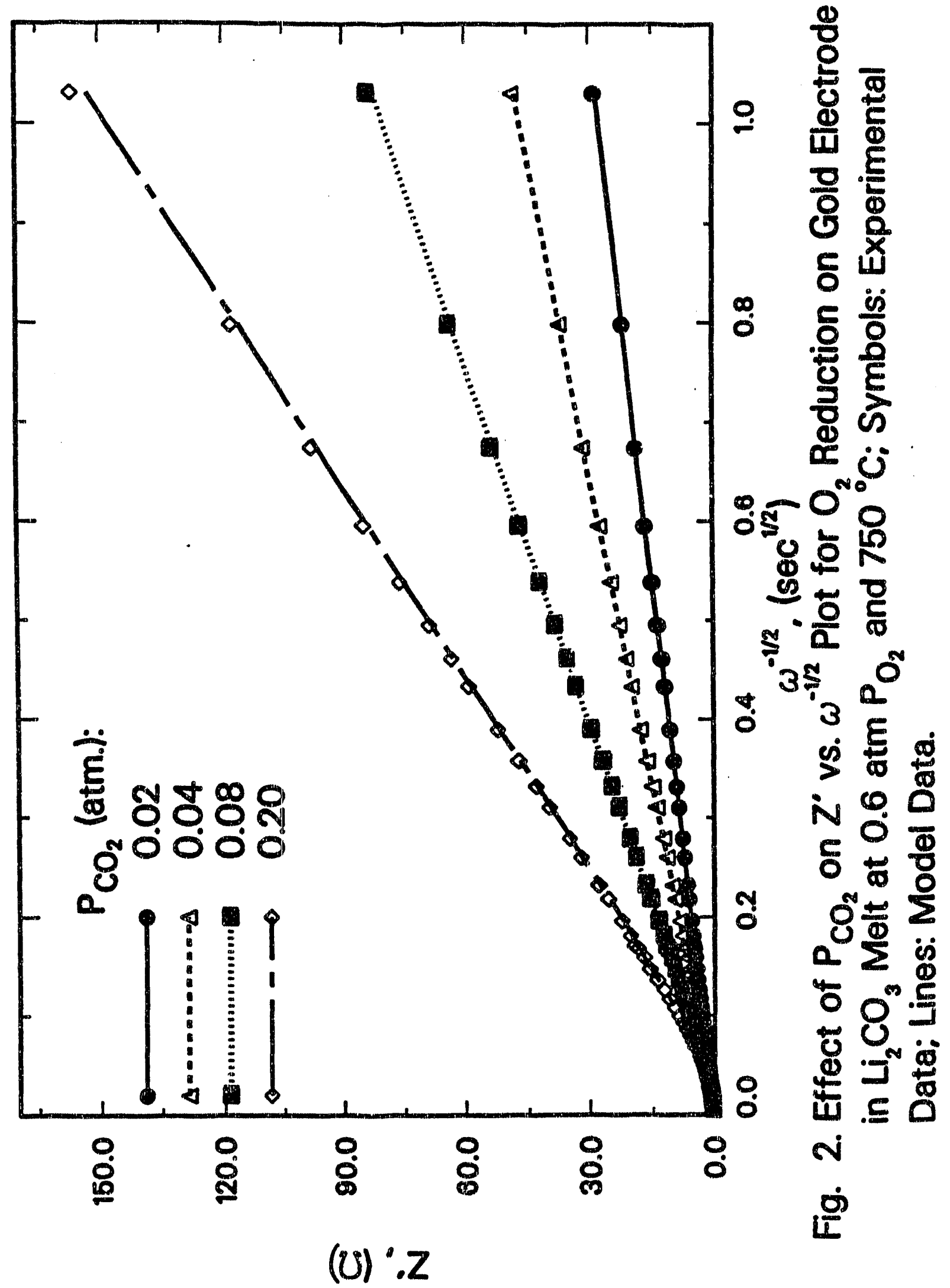




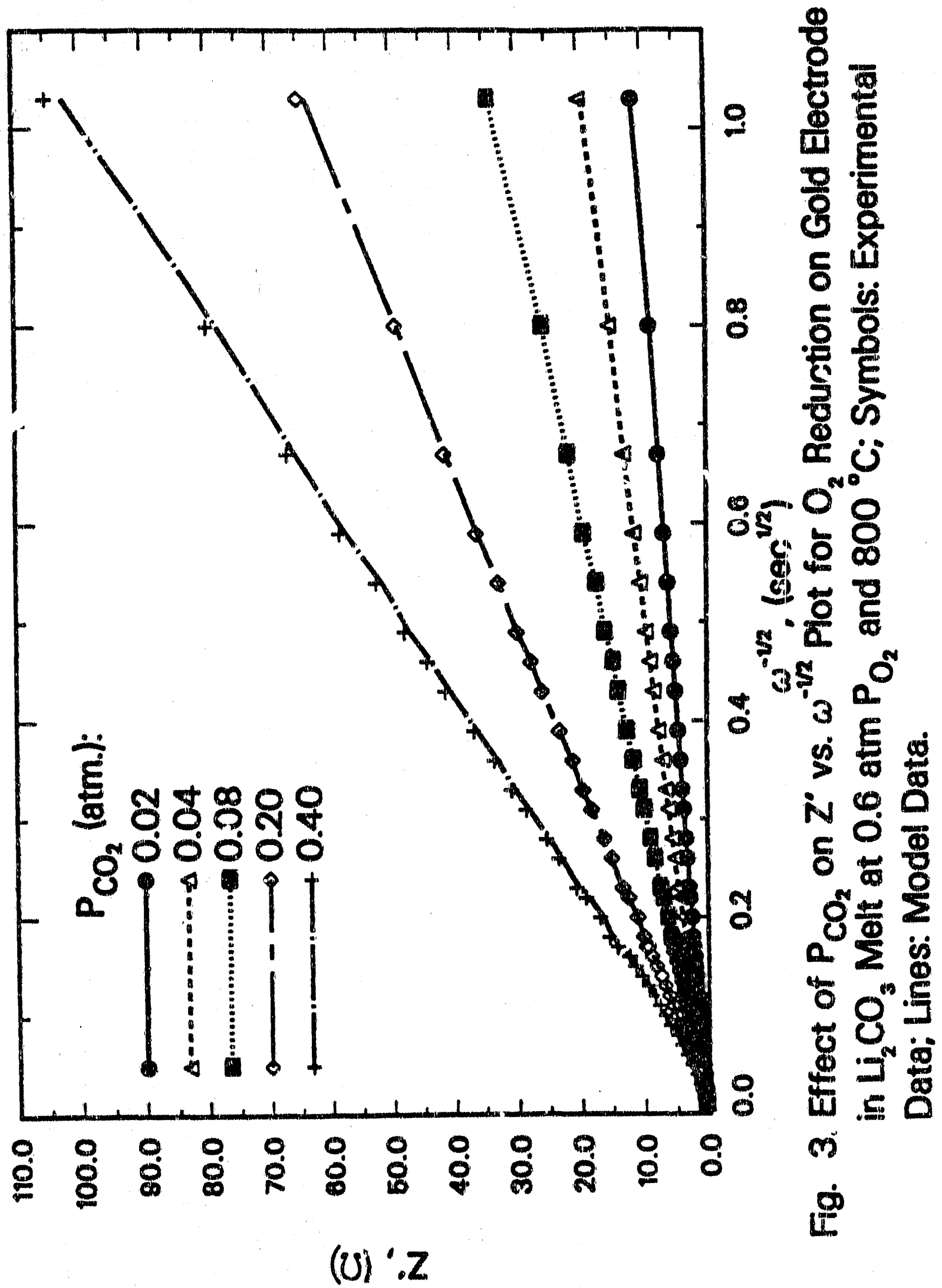




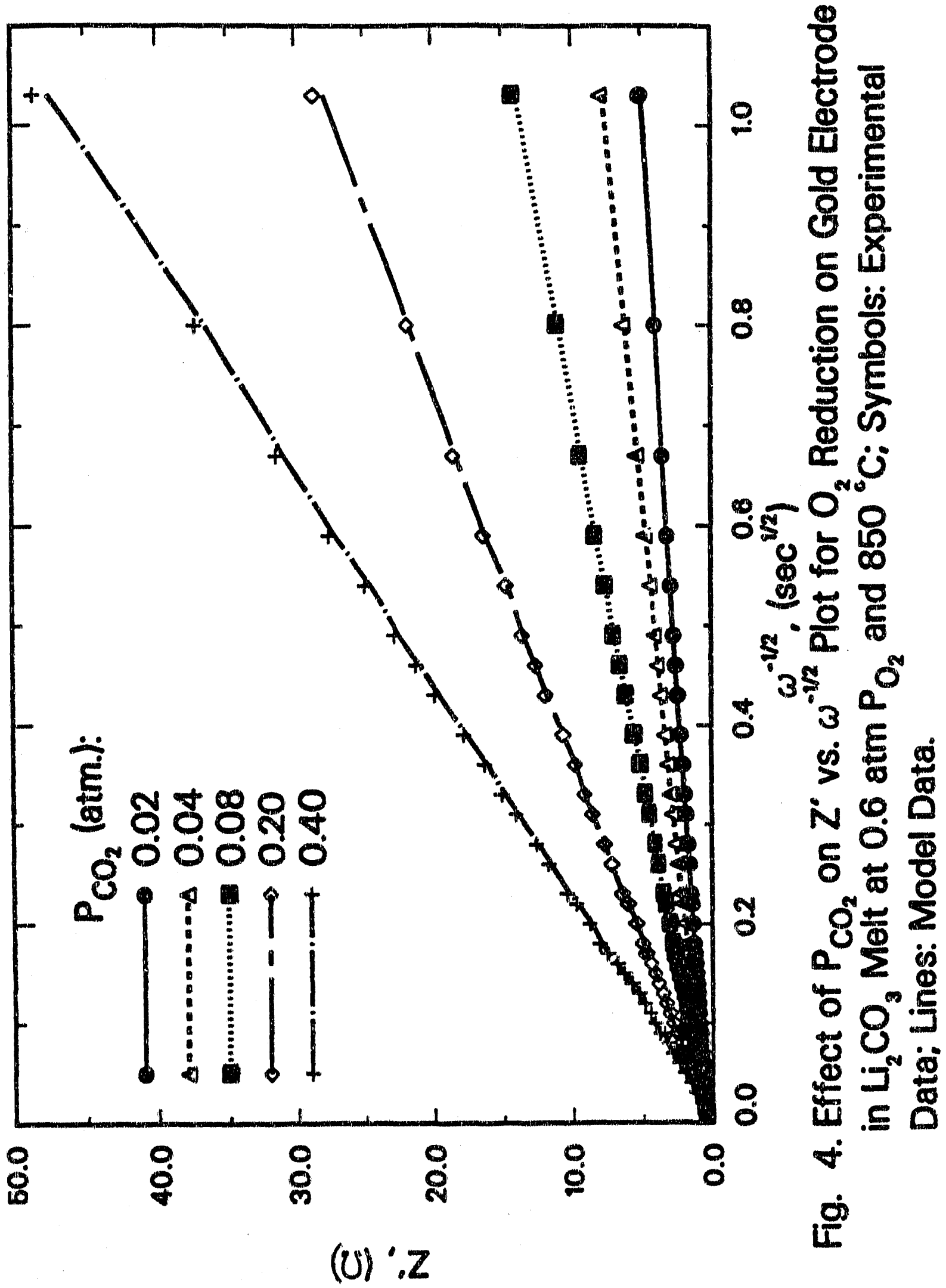




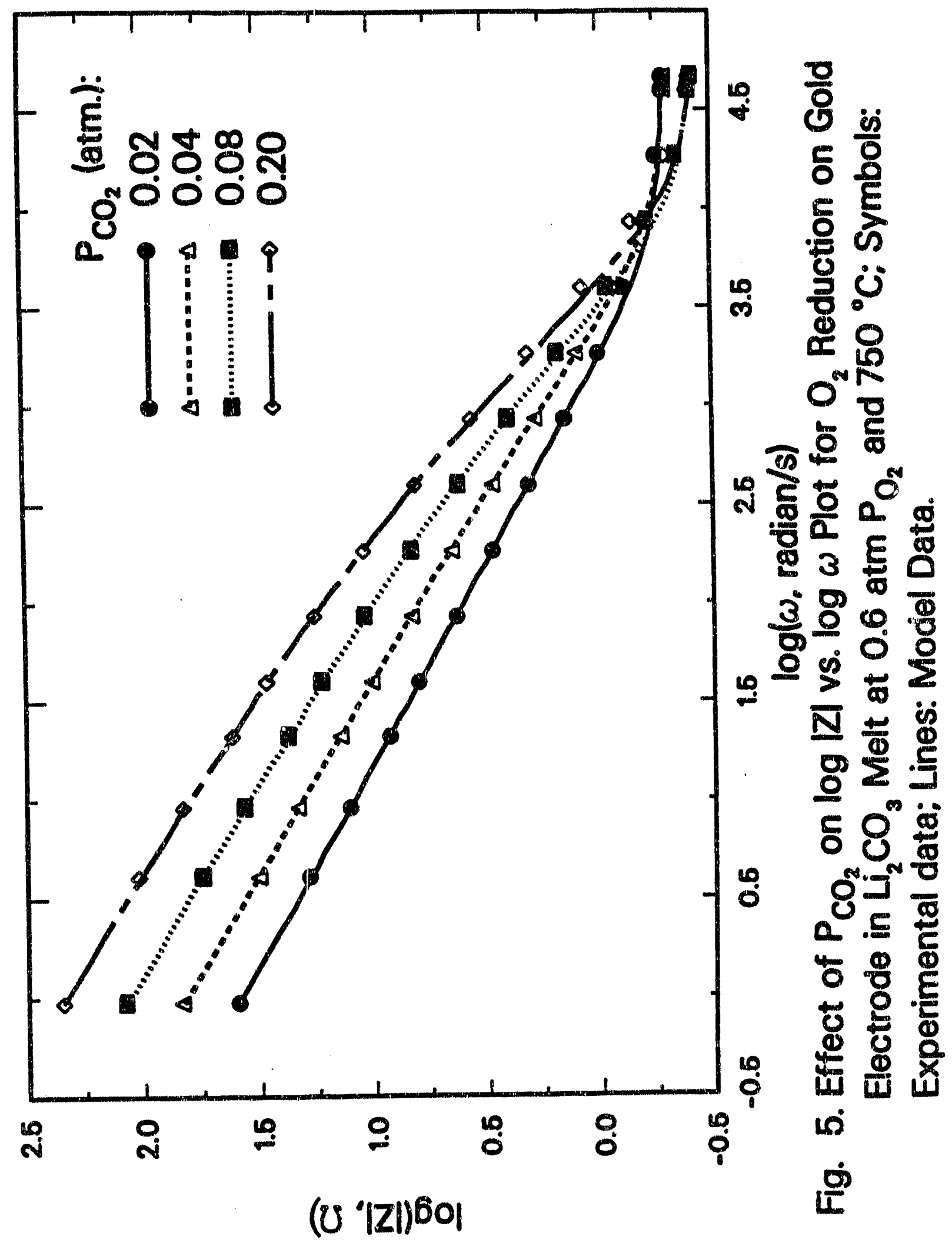




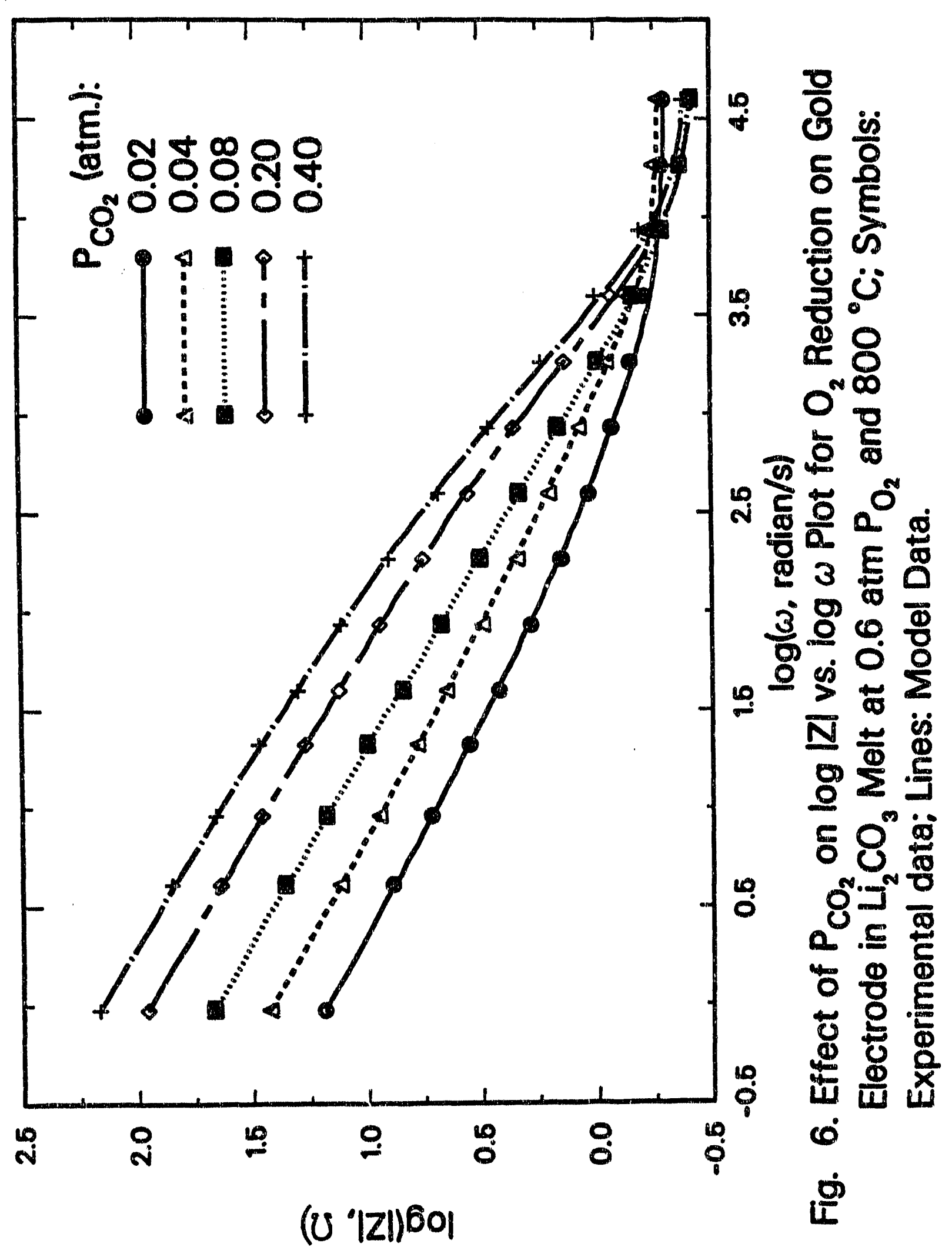




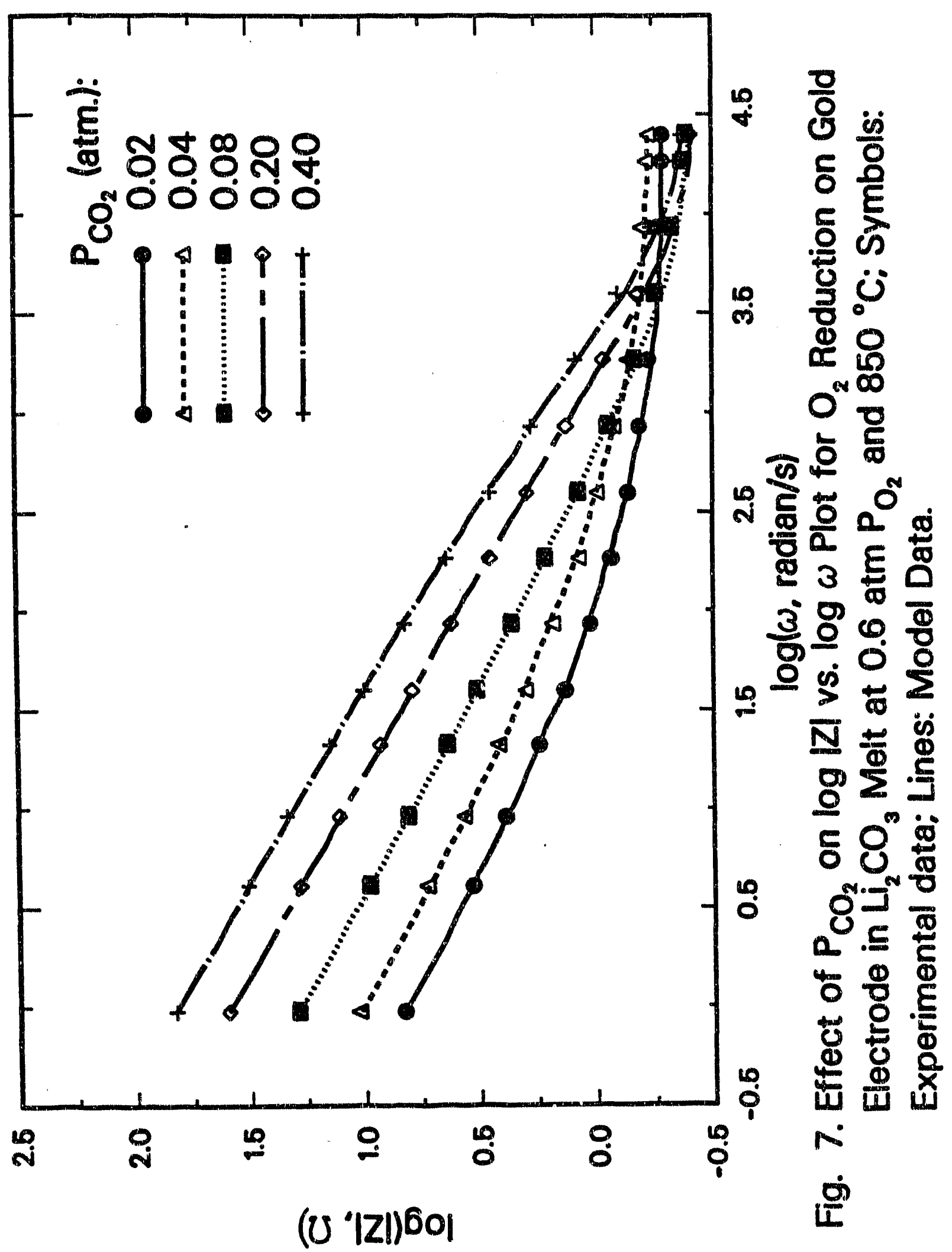




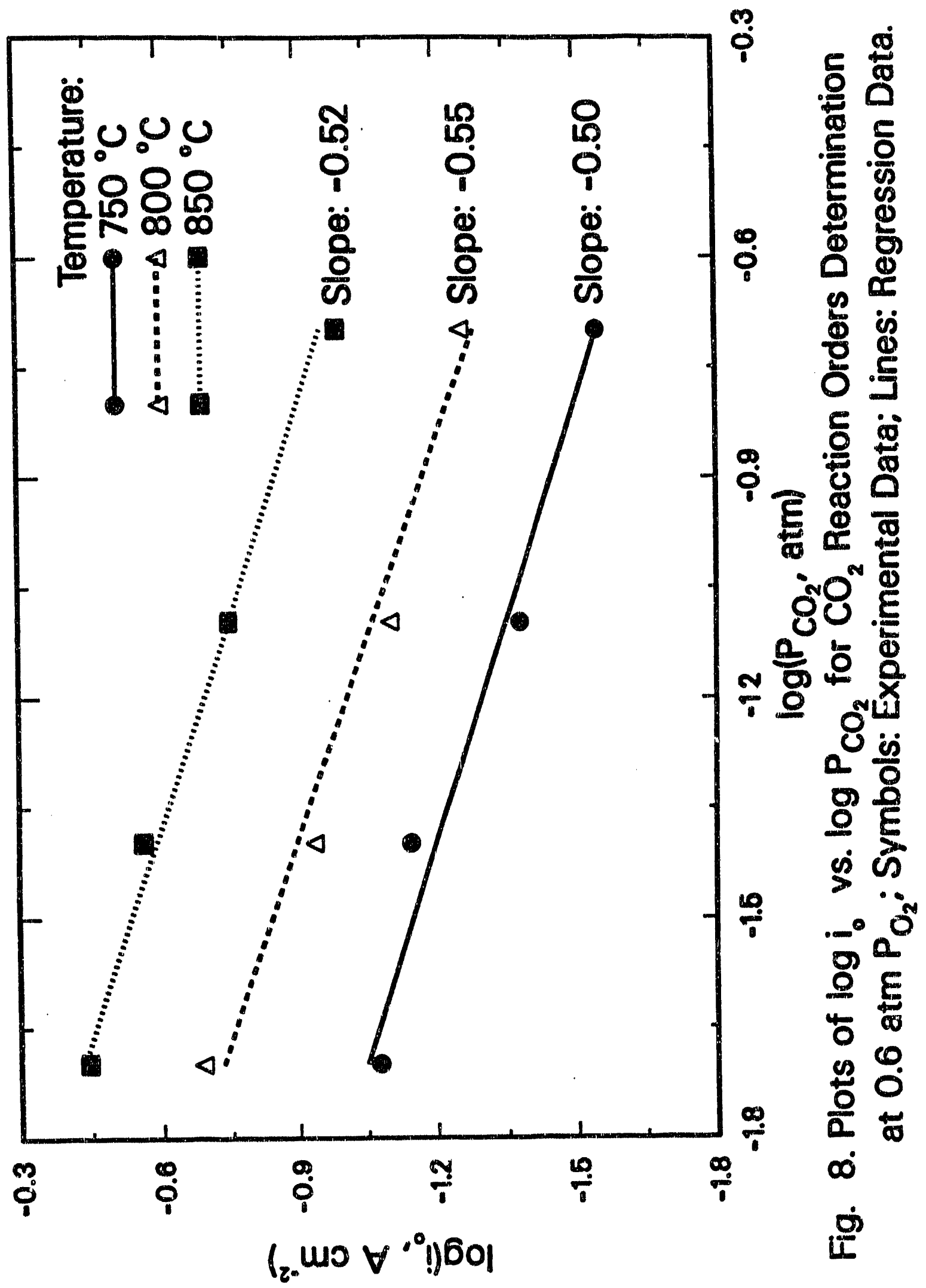




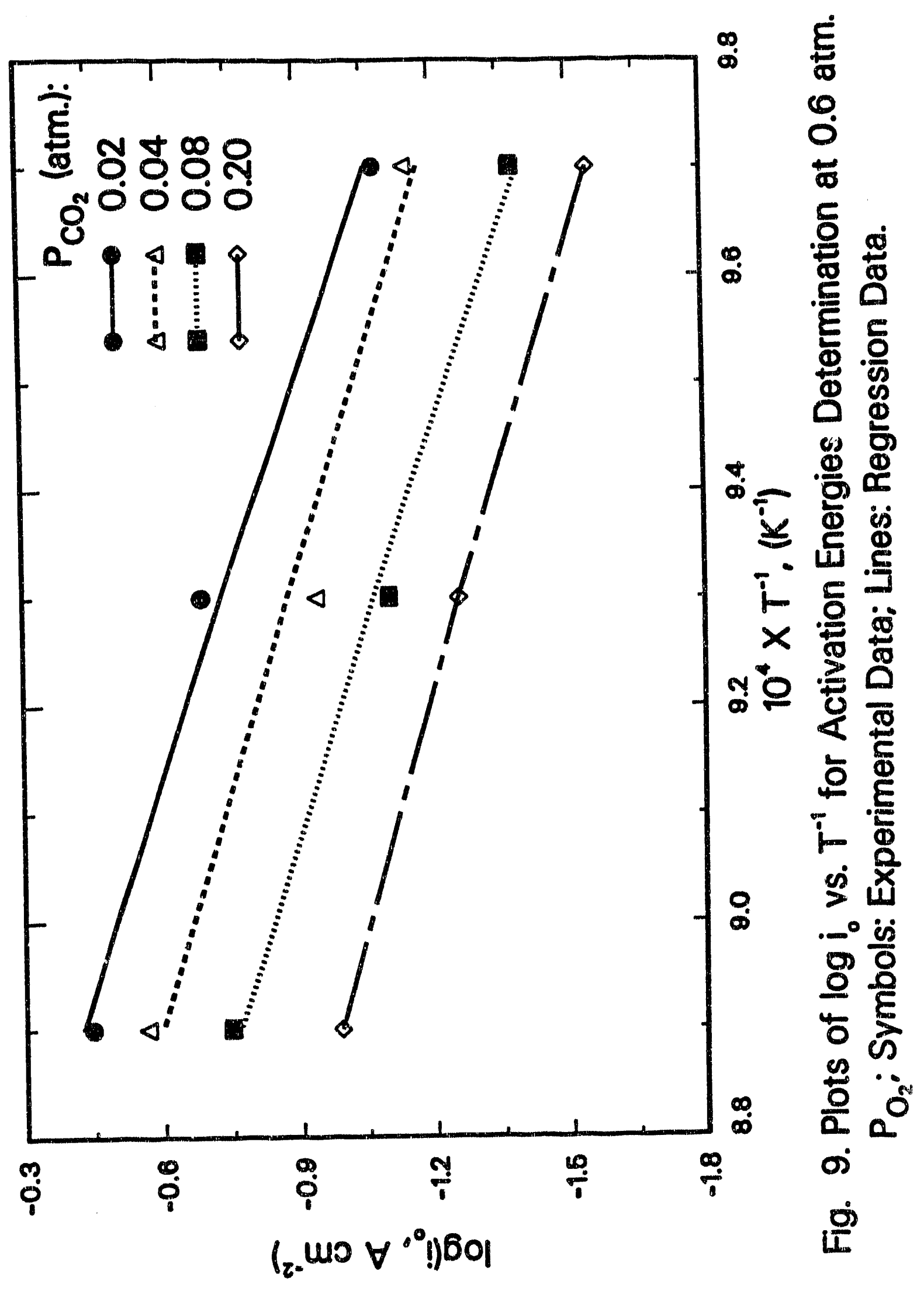




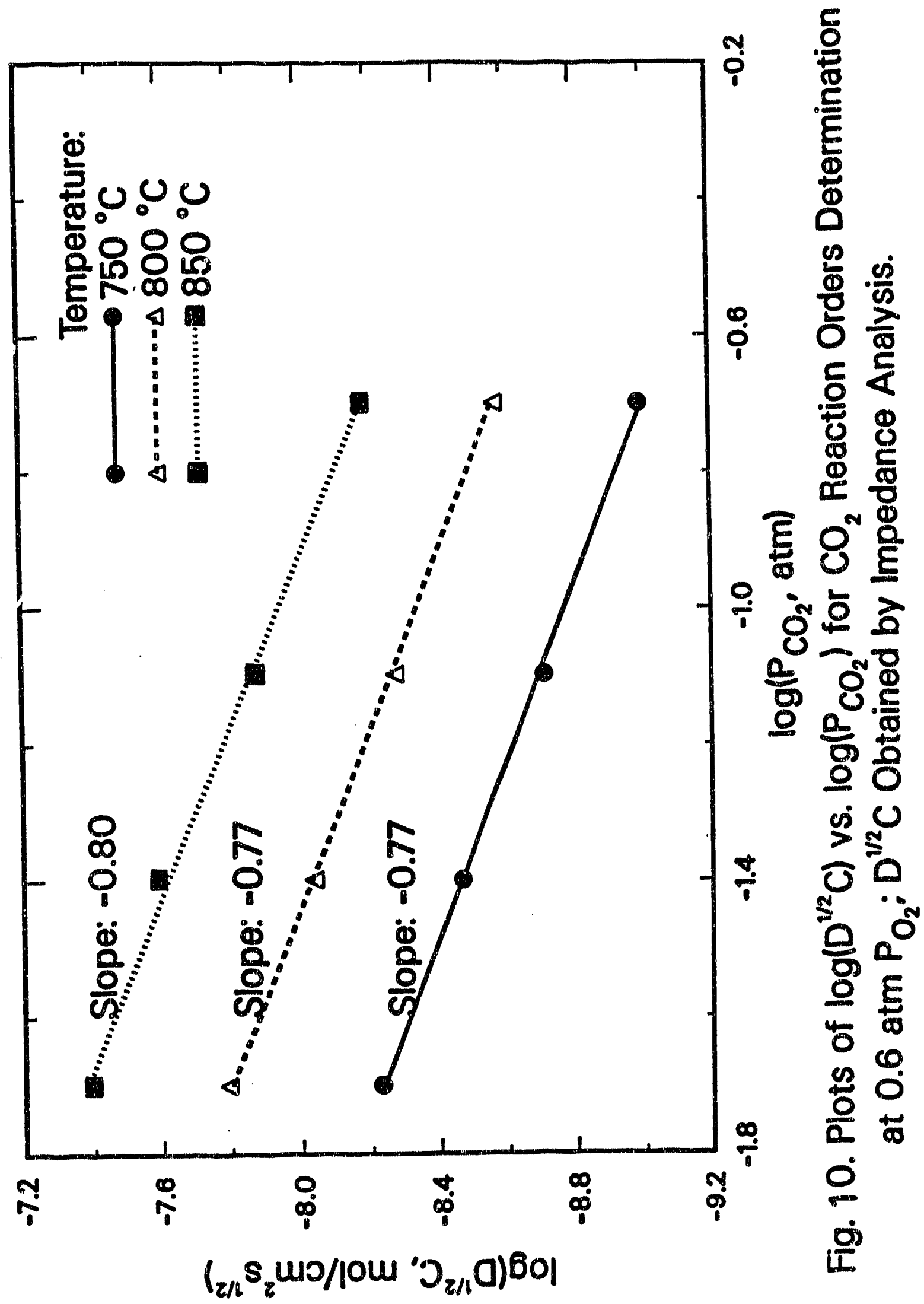




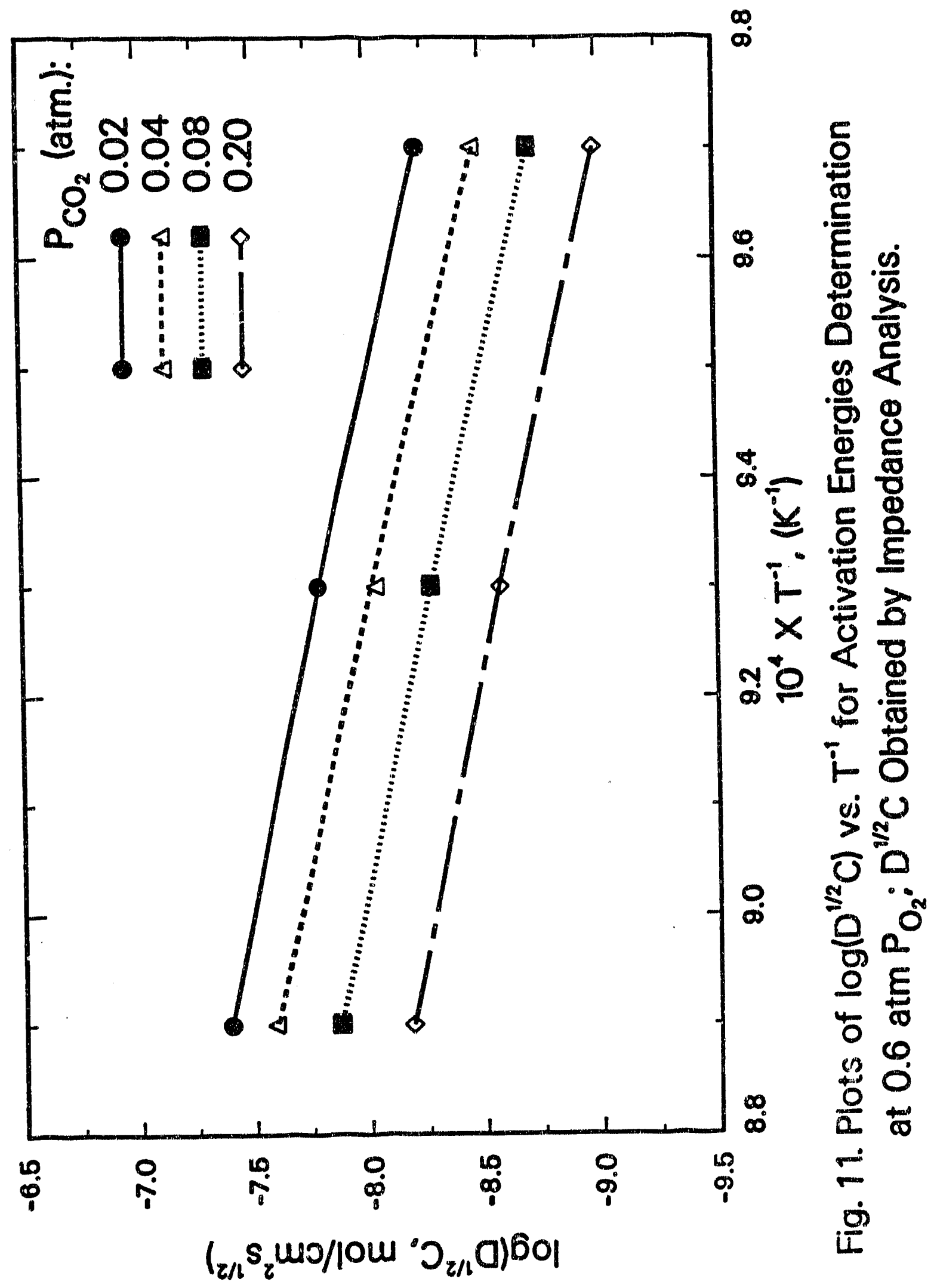



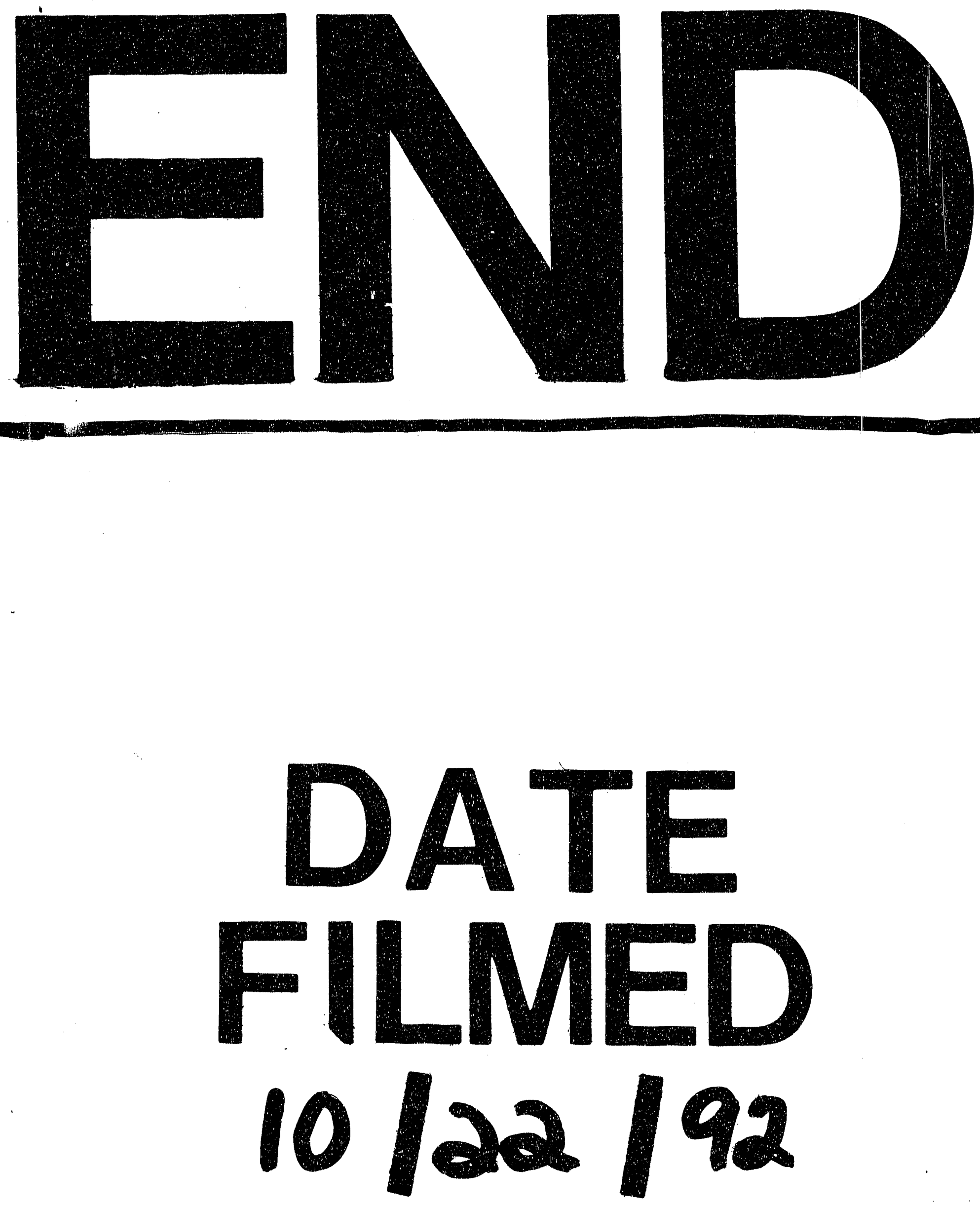
